Здійснений аналіз дозволяє дійти висновку щодо загальної задоволеності педагогічного персоналу рівнем корпоративної культури в університеті. Її найважливішими цінностями визнано доцільну організацію діяльності педагогічного та допоміжного персоналу, можливість професійного та кар'єрного зростання тощо. Подальший розвиток корпоративної культури в університеті зумовлений необхідністю облаштування комфортних робочих місць для педагогічного й допоміжного персоналу, оновлення навчально-матеріальної бази; налагодженні ефективної системи комунікації; забезпеченні можливості делегування повноважень на всіх рівнях управління; відновлення системи матеріального заохочення працівників тощо.

Розвиток корпоративної культури $є$ нині одним із пріоритетних напрямів розвитку будь-якої організації. Проте незважаючи на наявність грунтовної теоретичної бази щодо вивчення корпоративної культури комерційних організацій, відповідні здобутки для корпоративної культури в закладах освіти досить обмежені. На нашу думку, переносити теорію корпоративної культури організацій як таких на заклади освіти можна лише з урахуванням специфіки їх діяльності, специфіки послуг, що вони надають, i, нарешті, специфіки персоналу, що забезпечує надання освітніх послуг.

\title{
Література
}

1. Галкина Т. П. Социология управления: подготовка группы к команде:[учеб. пособ.] / Т. П. Галкина. - М. : Финансы и статистика, 2001. - С. 192-195. 2. Семенов Ю. Г. Организационная культура: управление и диагностика/ Ю. Г. Семенов. - Екатеринбург : Ин-т экономики УрОРАН, 2004. - 180 с. 3. Яценко А. М. Організаційно-культурні ресурси і механізми соціального управління:[монографія] / А. М. Яценко. - Одеса : Астропринт, 2003. - 205 с.

\section{ХУДОЖНЬО-ЕСТЕТИЧНИЙ СМАК ДІТЕЙ СТАРШОГО ДОШКІЛЬНОГО ВІКУ ТА ОСОБЛИВОСТІ ЙОГО ВИЯВУ}

Лазаренко Г. А. Художньо-естетичний смак дітей старшого дошкільного вікута особливості його вияву.

У дослідженні виявлені питання особливостей вияву художньо-естетичного смаку дітей старшого віку, а саме: емоційні реакції, їх потреби у сприйманні прекрасного, особливості сприйняття навколишніх i музичних звуків. Також 3'ясовано, що допомагають виявитися художньо-естетичному смаку музичнотеатральна діяльність, виконавська та творча активність дошкільників.

Ключові слова: художньо-естетичний смак, діти старшого дошкільного віку, емоції, сприйняття, музика.

Лазаренко Г. А. Художественно-эстетический вкус детей старшего дошкольного возраста и особенности его проявления.

В исследовании выявлены вопросы особенностей проявления художественноестетического вкуса детей старшего дошкольного возраста, а именно: эмоциональные реакции, потребность в восприятии прекрасного, особенности восприятия окружающих и музыкальных звуков. Так же выявлено, что помагают проявиться художесвенноэстетическому вкусу музыкально-театральная деятельность, исполнительская и творческая активность дошкольников.

Ключевые слова:художественно-эстетический вкус, дети старшего дошкольного возраста, эмоции, восприятие, музыка. 
Lazarenko G. A. Artistic and aesthetic taste of preschool children and especially its manifestation.

In research questions of features of display of artly-esteticheskogo taste of children senior preschool age are revealed, namely: emotional reactions, requirement for perception fine, features of perception of surrounding and musical sounds. As it is revealed, that помагают to be shown to hudozhesvenno-aesthetic taste is musical-theatrical activity, performing and creative activity of preschool children.

Keywords: is art-aesthetic taste, children of the senior preschool age, emotion, perceptions, music.

Нині перед науковцями постає багато нерозв'язаних питань, щодо оновлення навчально-виховного процесу в дошкільних закладах. Сучасний освітній простір має характер інформаційної насиченості, динамічності та багатогранності видів і форм інтелектуально-пізнавальної, художньо-естетичної, практичної діяльності. Ця тенденція зумовлює природне ускладнення соціальних ролей, функцій та обов'язків особистості в колективі. Вдало подолати потреби суспільства під силу лише дитині, яка в дитячому закладі набула певного комплексу знань, умінь і навичок, яка має розвинений інтелектуальний i творчий потенціал, високий рівень культурного спілкування, поведінки, мислення, демонструє власні ціннісні орієнтири, моральні якості, має багату палітру естетичних уявлень, почуттів, художньо-естетичних смаків. Для досягнення дошкільниками подібних якостей потрібно оновлення навчальновиховного процесу, обов'язковим компонентом якого повинні бути теоретичні i практичні заняття мистецтвом.

Останні роки все більше науковців звертають свою увагу на вдосконалення дошкільної освіти. 3'являється низка сучасних досліджень, присвячених теоретичним та практичним питанням художньо-естетичного розвитку дошкільників. Так I. Молодушкіна у своєму посібнику «Загадковий світ ємоцій. Розвиток емоційної сфери дошкільників» [1], розкриває низку методів і форм роботи з розвитку емоційної сфери дошкільнят. Л. Шик розробила посібник для дитячих навчальних закладів на допомогу вихователям та музкерівникам «Театралізована діяльність дошкільників. Художньо-естетичний розвиток» [6]. С. Нечай у своїй статті «Дитина і звуки світу» [5] розкриває значення аудіального розвитку дитини дошкільного віку. Але питання особливостей вияву художньо-естетичного смаку дітей старшого дошкільного віку є недостатньо розкритим.

Метою статті є вивчення питань, що пов'язані з особливостями вияву художньо-естетичного смаку в дітей старшого дошкільного віку на заняттях 3 музичного мистецтва.

В основу дослідження покладено ідею Л. Молчанової, яка у своїй книзі «На смак та колір» уважає, що художньо-естетичний смак поєднує емоції, естетичні почуття, естетичні сприйняття, естетичну оціночну діяльність й естетичні потреби особистості [4, с. 56-57]. Спираючись на цю ідею, можна виокремити кілька особливостей вияву художньо-естетичного смаку в дітей старшого дошкільного віку.

По-перше, це виражені емоційні реакції. Шестирічна дитина - істота емоційна: емоції $€$ панівними над усіма її сторонами життя, надаючи їм особливого забарвлення. Дитячі короткочасні емоційні реакції швидко та яскраво спалахують, реагуючи на визначений об'єкт, ситуацію або подію, і дитина вже здатна пояснити свої уподобання, прихильність чи неприязнь до них. 
На розвиток емоційної сфери впливає багато чинників. У старшому дошкільному віці (5,5- 7 років) відзначається бурхливий розвиток і перебудова в роботі всіх фізіологічних систем організму дитини: нервової, серцево-судинної, опорно-рухової. Дитина швидко додає у зростанні і вазі, змінюються пропорції тіла. Відбуваються істотні зміни вищої нервової діяльності. Організм дитини в цей період свідчить про готовність до переходу на інший ступінь вікового розвитку

Старший дошкільний вік відіграє особливу роль у психічному розвитку дитини: в цей період життя починають формуватися нові психологічні механізми діяльності та поведінки. Закладаються основи майбутньої особистості: формується стійка структура мотивів; зароджуються нові соціальні потреби, спільна 3 дорослим діяльність змінюється самостійним виконанням вимог, вказівок, доручень, прохань дорослого [1, c. 191]. Виникає потреба у стабілізації взаємин з однолітками, потреба утворення «дитячого суспільства», утворення дитячої субкультури з притаманною їй територією, правилами співжиття, інтересами, ролями, перевагами, пріоритетними цінностями, соціальним статусом кожного їі члена [1, с. 187].

Одним із найважливіших досягнень старшого дошкільного віку є усвідомлення свого соціального «Я», формування внутрішньої соціальної позиції. У старшому дошкільному віці дитина вперше усвідомлює розбіжність між тим, яке положення вона займає серед інших людей, і тим, які іiі реальні можливості і бажання. 3'являється яскраво виражене прагнення до того, щоб зайняти нове більш «доросле» становище в житті і виконувати нову, важливу не тільки для неї самої, але і для інших людей діяльність [1, с. 188].

Емоційне спілкування повинно бути естетичним, красивим, сповненим теплоти та гуманного ставлення до тих, хто знаходиться поруч. Передача більш глибоких власних емоцій - достатньо складний процес, що потребує від дитинипевних знань, певного рівня розвитку. Збагачувати внутрішній світ дитини позитивними емоціями, насичувати іiі життя приємними враженнями, створювати психологічний клімат, розширювати та поглиблювати уявлення дитинипро людські переживання, моральні, пізнавальні, естетичні почуття, сприяти оволодінню «азбукою» емоцій, учити добирати відповідні способи вияву своїх почуттів потрібно на заняттях художньо-естетичного циклу: музичної, образотворчої, театралізованої діяльності. Це дозволяє дітям у подальшому стати господарями свого життя і сміливо виявляти власні смаки $[2$, с. 6].

По-друге, це потреби шестирічної дитини у сприйнятті чогось прекрасного, казкового, фантастичного. Провідною діяльністю старшого дошкільника $є$ сюжетнорольова гра. Дошкільняті властива підвищена пізнавальна активність. Емоційна сприймальна чутливість, образне мислення, оскільки саме в цьому віці інтенсивно розвиваються уява, фантазія, пам'ять. Дитина здатна не лише сприймати красу довкілля й певним способом по-своєму відтворювати іiі, вона прагне також розкритись у власних природних здібностях, самореалізуватися. Тож музичне мистецтво і казка допомагає їй у цьому [2, с. 16]. Найбільш цікаві ігри для дитини: казково-музичні ігри, ігри-інсценізації, драматизації, які поєднують у собі фантастичну пригоду або казку і музичний супровід. У такі ігри діти вкладають чимало творчих зусиль, що і характеризується як вияв художньо-естетичного смаку.

Задля задоволення потреби дитини у сприйнятті прекрасного можна використовувати музично-театральну діяльність. В основі музично-театральної діяльності лежить розвиток емоційної чутливості до прекрасного, негативного ставлення до потворного. Музично-театралізована діяльність є ефективним засобом педагогічного впливу на розвиток особистості дошкільника. Вона передбачає 
формування в дошкільників умінь «входити в образ» та «утримувати» його впродовж усієї театралізованої діяльності; усвідомлювати мовленнєві та виконавські дії; передавати характерні особливості різних художніх образів; переносити здобуті уявлення в самостійну ігрову діяльність; прищеплювати дітям інтерес до театру як до виду мистецтва [6, с. 6].

По-третє, це сприйняття світу у звуках. Створювати цілісну картину світу допомагає дитині набуття досвіду в ході слухового розвитку, здастність сприймати та добре диференціювати звукові сигнали довкілля, вміння визначити їхню якість. Цей розвиток грунтується на вмінні слухати, чути й розуміти самого себе, людське оточення, навколишній шумовий, звуковий і музичний світ. Ефективність слухового розвитку дошкільнят залежить від уміння вихователя уникати прямого повідомлення необхідних знань, створювати ситуації, що сприятимуть самостійному пошуку відповідей на запитання, способів діяльності, виховувати нестандартне мислення, формувати художньо-естетичні смаки.

На музичних заняттях відповідно до тематики шумів і звуків навколишнього середовища дітям доцільно слухати й аналізувати програмні музичні твори 3 відповідним образом. Музичні образи спонукають до співчуття і співпереживання. Тому на шляху до розуміння музичного мистецтва діти стають активними співучасниками творчого процесу [5, с. 17-20].

У процесі сприйняття звуків у дітей старшого дошкільного віку відбувається інтенсивний всебічний розвиток. Ознайомлюючи дітей 3 різними звуками, які передають внутрішній стан людини, іiі почуття й думки, важливим завданням $€$ навчити дитину виявляти власні почуття під час виконавської діяльності. Здатність усвідомлювати виконавський характер твору і вміння співвідносити власне музичне виконавство з виконавством інших $є$ одним із показників ступеня сприйняття, оцінки та власної інтерпретації.

Виконавство притаманне всім видам музичної діяльності. Співи найдоступніший вид музично-виконавської діяльності, оскільки його інструментом $€$ голос. Діти із задоволенням займаються співом, вокалом, і вдало виявляють свої смаки у виконанні тієї чи іншої пісні. Інструментальне музикування також сприяє вияву художньо-естетичного смаку дошкільників: ознайомлення з різними музичними іграшками та інструментами збагачує пізнавальну та емоційнусфери особистості. Відтворюючи живі звуки, юні музиканти отримують безліч позитивних емоцій, під впливом яких розкривається творчий потенціал особистості. Участь в оркестрі привчає кожну дитину до взаєморозуміння з іншими. Залучаючи дітей до музичнорухової діяльності, ми намагаємося збагатити сприйняття дитини рухливими реакціями. Тому рухи успішно використовуються як засіб активізації розуміння дітьми характеру музики, іiї образного змісту [5, с. 9].

Особливості вияву художньо-естетичного смаку полягають у розвиненій емоційній сфері дитини.Чим більше розвинена емоційна сфера дитини, тим легше їй виразити своє ставлення до довкілля, творів мистецтва, виявити власну індивідуальність. Сприйняття прекрасного, фантастичного допомагає пізнати духовні цінності, розвиває вміння розуміти, розрізняти і цінувати красиве й потворне в житті і мистецтві. Дитяче музичне виконавство, музично-театралізована діяльність допомагають у процесі виявлення художньо-естетичного смаку старших дошкільників.

Перспективою подальших розробок в окресленому напрямі дослідження $\epsilon$ перевірка на практиці методів та форм роботи 3 дітьми дошкільного віку 3 формування в них художньо-естетичного смаку, враховуючи їхні вікові та 
індивідуальні особливості.

\section{Література}

1. Базова програмарозвитку дитини дошкільного віку «Я у Світі» / наук. кер. та заг. ред. О. Л. Кононко. - [3-те вид., випр.]. - К. : Світич, 2009. - 430 с. 2. Еманова 3. І. Музично-виконавська діяльність: сучасні підходи / 3. І. Еманова // Дошкільне виховання. - К. : Світич, 2009. - № 8.- С. 14-17. 3. Загадковий світ ємоцій. Розвиток емоційної сфери дошкільників / упоряд. І. В. Молодушкіна. - Х. : Вид. група «Основа», 2010. - 207 с. 4. Молчанова А. С. На вкус и цвет/ А. С. Молчанова. - М. : Искусство, 1966. - 200 с. 5. Нечай С. О. Дитина і звуки світу / С. О. Нечай // Дошкільне виховання.- К. : Світич, 2011. - № 7. - С. 17-20. 6. Театралізована діяльність дошкільників. Художньо-естетичний розвиток / упоряд. Л. А. Шик. - Х. : Вид. група «Основа», 2011. - 176 с.

УДК $378.147: 371.38$

Віктор Мадзігон

\section{КОМПЕТЕНТНІСНИЙ ПІДХІД У СИСТЕМІ НЕПЕРЕРВНОЇ ЕКОНОМІЧНОЇ ОСВІТИ}

Мадзігон В. В. Компетентнісний підхід у системі неперервної економічної освіти.

У статті досліджуються напрями вдосконалення парадигми розвитку національної економічної освіти в контексті інноваційного оновлення іiі змісту, обгрунтовуються теоретико-методичні засади формування професійних знань майбутніх фахівців економічного профілю в системі неперервної освіти як важливої передумови розбудови економіки знань.

Ключові слова:освіта, економічна освіта, парадигма, професійна компетентність, фахівці економічного профілю, система знань, інноваційна економіка, неперервна освіта, економіка знань.

Мадзигон В. В. Компетентностный подход в системе непрерывного экономического образования.

В статье исследуются направления усовершенствования парадигмы развития национального экономического образования в контексте инновационного обновления ее системы, обосновываются теоретико-методические основы формирования профессиональных знаний будущих специалистов экономического профиля в системе непрерывного образования как важное условие развития экономики знаний.

Ключевые слова:образование, экономическое образование, парадигма, профессиональная компетентность, специалисты экономического профиля, система знаний, инновационная экономика, непрерывное образование, экономика знаний.

Madsigon V. V. Competent approach to the Economic education system continuously.

The article examines the ways of improving the national economic development paradigm of education in the context of the renewal of its innovative system. The author justifies the theoretical and methodological basis for the formation of professional knowledge of future specialists in economics in the system of continuous education as an important condition for the development of the knowledge economy.

Key words:education, economic education, paradigm, professional competence, experts in economics, a system of knowledge, innovation economy, continuous education, knowledge economy. 